\title{
GaN基板上GaN系半導体レーザーの現状
}

\author{
長濱慎一 \\ 日亜化学工業(株) 第2部門LD技術本部LD開発部（テ774-8601 徳島県阿南市上中町岡491番地）
}

\section{Current Status of GaN-Based Laser Diodes Grown on Freestanding GaN Substrate}

\author{
Shin-ichi NAGAHAMA \\ LD Development Department, LD Engineering Division, Optoelectronics Products BU, \\ Nichia Corporation, 491 Oka, Kaminaka, Anan, Tokushima 774-8601
}

(Received July 25, 2006)

\begin{abstract}
The development of optical memory devices that use violet laser diodes (LDs) has progressed significantly and these devices have been commercialized. The need for high-speed recording and multilayer recording is increasing, and it is expected that even higher power LDs will be necessary in the future. In this paper, the current state of GaN-based LD research for the next generation optical memory devices is reported, and next targets are discussed. Moreover, we developed high power pure blue laser diodes for full-color laser display. The details of these pure blue LDs characteristics are reported.
\end{abstract}

Key Words: Laser diode (LD), AlInGaN, GaN substrate, Blue laser

\section{1. 緒 言}

1995年にGaN系材料を用いた波長 $405 \mathrm{~nm}$ の紫色半導体 レーザー1)が発表されて，10年以上が経過した。現在で は，紫色半導体レーザーを用いた次世代大容量光メモリ の実用化が進められている.今後は, より高速記録化, 多層記録化の要望も強くなってきており, 半導体レー ザーのさらなる高出力化が必要になってくると予想され る。また，最近では， $\mathrm{GaN}$ 系半導体レーザーの発振波長域 は, 紫外域2へあるいは, より長波長の青色域3)へと拡大 して, 医療, バイオ関連機器や, フルカラーレーザー ディスプレイ等への応用が期待されている。このうち, 特にフルカラーレーザーディスプレイへの応用を考えた 場合, 発振波長が440 nmから460 nmの純青色半導体レー ザーの高出力化が強く望まれている.

本稿では, 次世代大容量光メモリ用の紫色高出力半導 体レーザーの現状について報告し, 今後の課題について 述べる. 加えて, 近年ディスプレイ青色表示用として注 目されつつある青色半導体レーザーの最近の発展と現状 について詳細に報告する。

\section{2. 紫色高出力半導体レーザー}

\section{1 紫色高出力半導体レーザーの構造}

開発初期は, サファイア基板上に半導体レーザー構造 が作製されていた。この場合，レーザー素子寿命は数百
時間程度であり，実用レベルの信頼性が得られなかった。 これは，サファイア基板と $\mathrm{GaN}$ 間の格子不整合に起因する 貫通転位が高密度 $\left(10^{9} \sim 10^{10} / \mathrm{cm}^{2}\right)$ に存在するために，レー ザー結晶が劣化していたためである。 その結果, 発光効率 が低下しレーザー素子の長寿命化を阻んでいた，近年にな り結晶の低転位密度化技術の開発が進み，良質の GaN基板 の作製が可能となってきている。 そこで，われわれは，低 転位密度の自立 $\mathrm{GaN}$ 基板を用い ${ }^{4,5)}$ ，この基板上にレー ザーを作製し，レーザー素子の高出力化および長寿命化の 検討を行った。

Fig. 1に，今回われわれが作製した半導体レーザーの構 造概念図を示す．このレーザーは，GaN基板を用いること で上述したような格子不整合に起因する転位の発生が無い ため，基板と同等の低い転位密度を実現することができ る.レーザー構造はリッジストライブ構造で, 外側を $\mathrm{ZrO}_{2}$ 膜で覆うことで水平横方向の屈折率差を設けている。ま た，垂直横モードの制御には，キャリアを活性層内部に， 光をガイド層内部にそれぞれ分離して効率的に閉じ込める 分離閉じ込め構造を採用している. 紫色高出力半導体レー ザーでは，活性層はInGaN多重量子井戸構造を採用し，ガ イド層にはGaN層，クラッド層には $\mathrm{AlGaN}$ 層をそれぞれ用 いている. 特に, p 型クラッド層には $\mathrm{AlGaN} / \mathrm{GaN}$ 超格子 構造4)を採用することで, 動作電圧の低減を図っている. また，GaN基板が導電性を有しているため，董面に $\mathrm{n}$ 電極 を設ける対向電極構造となっており，従来の同一面に電極 を形成する構造に比べ, 活性層へ均等に電流注入が行え 


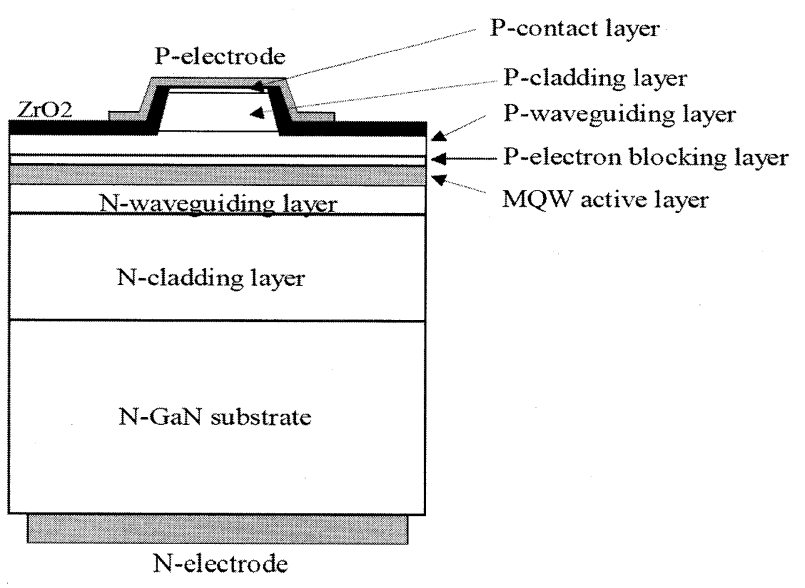

Fig. 1 Schematic strucure of GaN-based LDs.

る。このことは，横モードの安定化にも繋がっている. 導電性 $\mathrm{GaN}$ 基板を用いることで従来のサファイア基板上に 作製していた時よりも，作製プロセスが非常にシンプル になっている。

\section{2 紫色高出力半導体レーザーの特性}

光メモリ用半導体レーザーの高出力化で問題となるの がキンク (半導体レーザーの光出力ー動作電流特性におけ る非直線性のこと）の発生と出射端面の光学損傷 (Catastrophic Optical Damage；COD）である。キンクが発生 すると光ディスクを記録再生する際にエラーを生じてし まう。このためレーザーには，高出力領域までキンクフ リーを維持することが要求される。このため，導波路内 の光閉じ込め(特に水平方向)を制御する必要があり，一般 的にはストライプ幅を狭くする手法が取られる。狭くす ることで，レーザーの高次横モードの発生をカットオフ し，高出力領域までキンクレベルを向上することができ るためである。しかしながら，過剩に狭く設定すると， 水平横方向の光閉じ込めが強くなりすぎてしまい, COD レベルが下がるという副作用が生じてしまう。加えて， 狭ストライプ化は電極との接触面積が少なくなるため, 動作電圧の上昇も懸念される。われわれはこれら課題に ついて，レーザーのエピ層構造およびデバイス構造のさ まざまな最適化検討を行った。

Fig. 2に，ケース温度を $25^{\circ} \mathrm{C}$ ，パルス駆動（パルス幅： $10 \mu \mathrm{s}$ ，デューティ：5\%)条件下で測定した典型的な紫色 高出力半導体レーザーの電流-光出力 $(I-L)$ 特性および電流電圧 $(I-V)$ 特性を示す. 定格光出力 $130 \mathrm{~mW}$ 時のオペレー ション電流および電圧は, それぞれ $140 \mathrm{~mA}, 5.3 \mathrm{Vであ}$ る。またこの半導体レーザーのI- $L$ 特性の温度特性を Fig. 3 に示す.レーザーのケース温度を $20{ }^{\circ} \mathrm{C}$ から $80{ }^{\circ} \mathrm{C}$

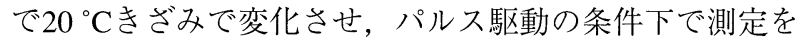
行った．全ての条件下に拈いて $200 \mathrm{~mW}$ までキンクフリー を実現できていることから，光閉じ込めが良好に行えて いることを示している。また，このレーザーの特性温度 $\left(20 \sim 80{ }^{\circ} \mathrm{C}\right)$ は $160 \mathrm{~K} て ゙ ，$ 温度依存性が少ないことを示して いる.

CODレベルを向上させるために，垂直方向の光閉じ込 めを調整し，導波路内の光密度の最適化を行った。また

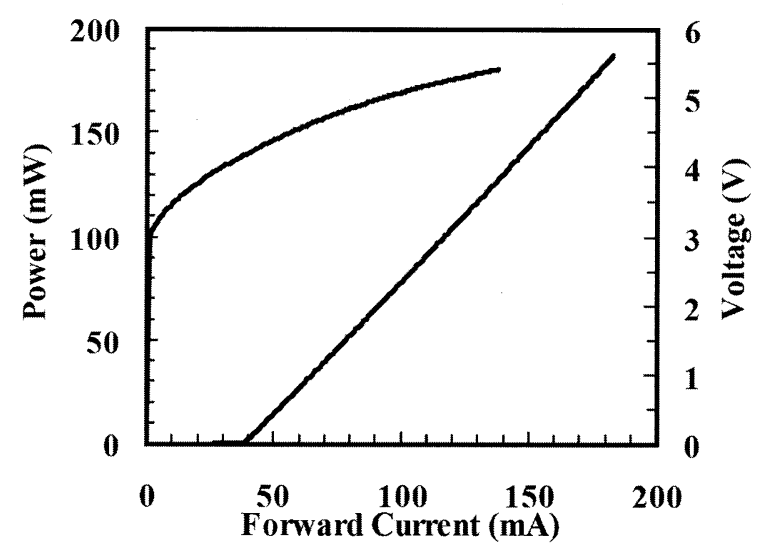

Fig. 2 Typical $I-L$ and $I-V$ characteristics of high power violet LDs.

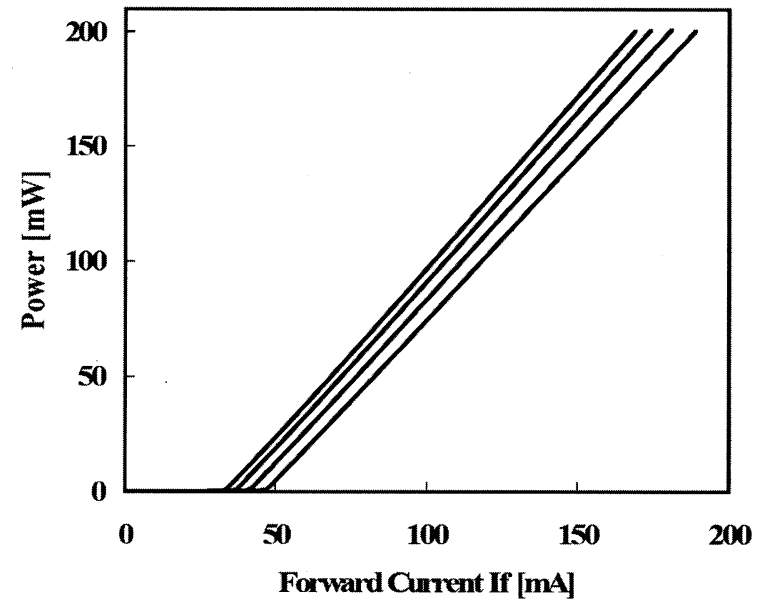

Fig. 3 Temperature dependence of $I-L$ characteristics.

同時に，端面保護膜の最適化も検討した。CODについて 調査した結果をFig. 4に示す。これより端面破壊が700 mW を越える出力のレベルで発生していることから，CODレ ベルについては十分な性能を有していることがわかる.

高温動作試験結果をFig. 5 に示す。測定条件は, レー ザーのケース温度を $70{ }^{\circ} \mathrm{C} に$ 設定し，パルス駆動(パルス 幅：30 nsec，デュティ：50\%)でレーザーに光出力 $130 \mathrm{~mW}$ を維持するようにAPC (Auto Power Controller) 駆動させ, 動作電流をモニターした。図から，レーザーは1000時間 以上安定して動作しており，この時の推定寿命は数千時 間となっている(動作電流が初期の1.3倍になった時がライ フエンドと定義)，高い信頼性が得られていることがわか る.

\section{3. 青色高出力半導体レーザー}

\section{1 しきい值電流の発振波長依存性}

本項では，405 nm带紫色半導体レーザーよりも発振波 長が長い青色領域でのレーザーの作製とその特性につい て述べる．Fig. 6に，2001年，2003年および2005年時点で のレーザー素子のしきい值電流密度の発振波長依存性を 示す。レーザーのケース温度を $25^{\circ} \mathrm{C}$, 連続動作 $(\mathrm{CW})$ の条 件下で測定を行った。活性層の成長温度をより低温で成 


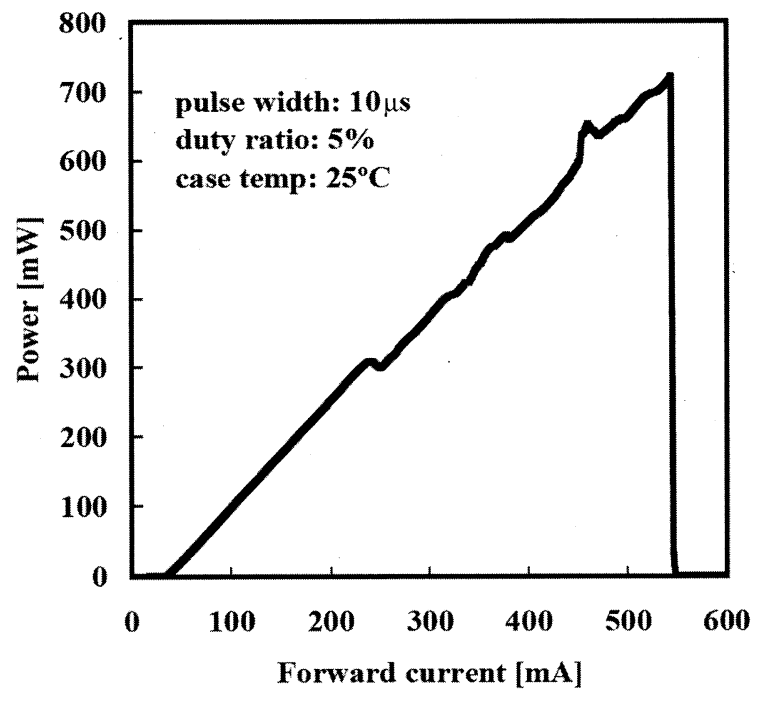

Fig. 4 Result of Catastrophic Optical Damage (COD) test.

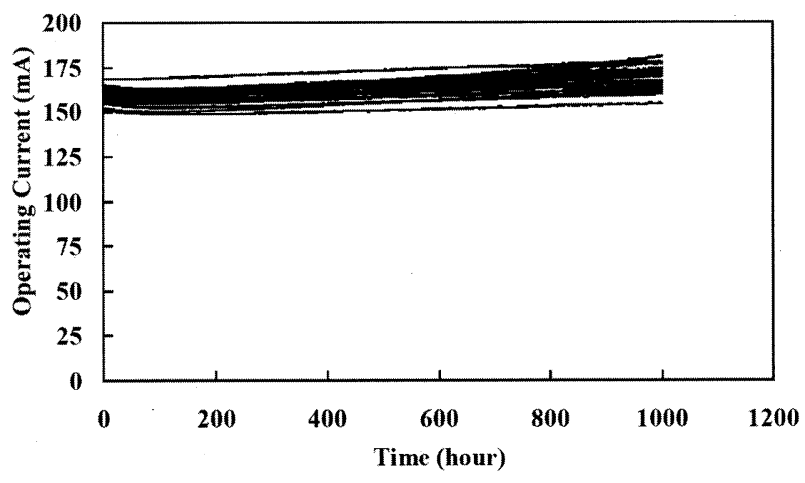

Fig. 5 Result of lifetime test of violet LDs under pulsed current operation at $70{ }^{\circ} \mathrm{C}$.

長を行うことで, 井戸層のIn組成比を増加させてレーザー の発振波長を長波長化させている。同図から, レーザー 素子のしきい值電流密度は発振波長に大きく依存し, 発 振波長が長波長になるにしたがって上昇することが分か る。また，2001年時点では，発振波長が $450 \mathrm{~nm}$ を超える としきい值電流密度が非常に大きくなり CW発振が実現で きなかったのに対し，2003年時点では $472 \mathrm{~nm} ， 2005$ 年で は482 nmとなり，開発年月を追うごとにCW発振が可能と なる最長波長が長くなっていることが分かる.

発振波長が長くなるにしたがってしきい值電流密度が 上昇する理由として, 活性層であるInGaN層中のInの空間 的組成摇らぎ6,7)による影響，およびエピ深さ方向の光閉 じ込めの減少が挙げられると思われる。このうち前者のIn 組成摇らぎについては，LEDの発光効率の向上には寄与し たが, レーザーの場合, 光学利得には寄与せず逆に吸収 として作用するため内部損失となる。したがって, 発振 波長が長い, すなわちIn組成の大きいレーザーでは, 内部 損失が増大し，しきい值電流密度が上昇すると考えられ る.また, 後者の光閉じ込め効果の減少に関しては, 波 長が長くなるほど屈折率の波長分散8)によりガイド/クラッ ド層間の屈折率差が低下することで光閉じ込めが低下 し，レーザー素子のしきい值電流が増大するためであ る.

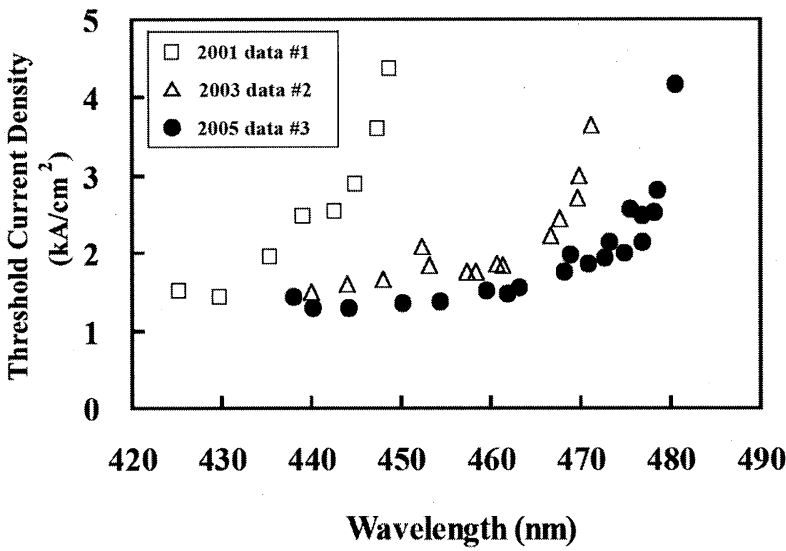

Fig. 6 Lasing wavelength dependence of threshold current density under $\mathrm{cw}$ operation at $25{ }^{\circ} \mathrm{C}$. (\#1: S. Nagahama, et al., Jpn. J. Appl. Phys. 40 (2001) 3075. \#2: S. Nagahama, et al., Proc. SPIE 4995 (2003) 108. \#3: K. Kozaki, et al., 2005 International Symposium Digest of Technical Papers 36 (2005) 1605.)

しかしながらわれわれは，これらしきい值電流上昇要 因に対し，主に基板の欠陷密度の低減化，InGaN活性層の 結晶性を向上させる結晶成長技術およびレーザーエピ構 造の最適化により，発振波長が482 nmの青緑色領域まで 発振波長の拡大に成功している。ささらに特記すべきは, Fig. 6の2005年時点でのデータ3)において, カラー表示とし ての青色の波長である450 nmから460 nmの領域まで，し きい值電流密度の上昇が見られないことである。このこ とは, 純青色半導体レーザーの発光効率が, GaN系半導体 レーザーの最も発振しやすい405 nm帯紫色領域のそれと ほぼ同じであり, 高出力化に関しても十分ポテンシャル があることを示していると思われる。

\section{2 青色高出力半導体レーザーの特性}

カラー表示としての青色LDに望まれる波長は, $440 \mathrm{~nm}$ から460 nmである。われわれはレーザーの波長を445 nm に設定して，レーザーの高出力化を図った。一般的に， 高出力化の方法には, 出射端面の光密度を低減するため に, 単一ワイドストライプ構造, マルチストライプ構造 などの構造が採られる。今回われわれが採用した構造 は，単一ワイドストライプ構造であり，ストライス幅を7 $\mu \mathrm{m}$ とした。レーザーの構造および作製の詳細に関して は，これまでに発表された報告3)に譲る。

Fig. 7は，発振波長445 nmのレーザーの典型的なI-L, I$V$ 特性である。測定は，レーザーのケース温度 $25{ }^{\circ} \mathrm{C}, \mathrm{CW}$ 駆動の条件下で行った。困から，しきい值電流は $98 \mathrm{~mA}$, 光出力 $500 \mathrm{~mW}$ 時の電流值および電圧值は, それぞれ 480 $\mathrm{mA}, 4.8 \mathrm{~V}$ であった. よって, 電力変換効率 (Wall- Plug Efficiency; WPE) は，21.7\%である。また，このレーザー の500 mW光出力時のスペクトルをFig. 8に示す. 図から, ピーク発振波長は $445.5 \mathrm{~nm} ゙$ あり, 縦マルチモード発振し ていることが分かる.

Fig. 9に, このレーザーをパルス電流(パルス幅: $2 \mu \mathrm{s}$, デューティ： $1 \%)$ 拈よびCW駆動した場合の $I-L$ 特性の比較 図を示す，図から，CW駆動時の光出力は, 発熱による影 


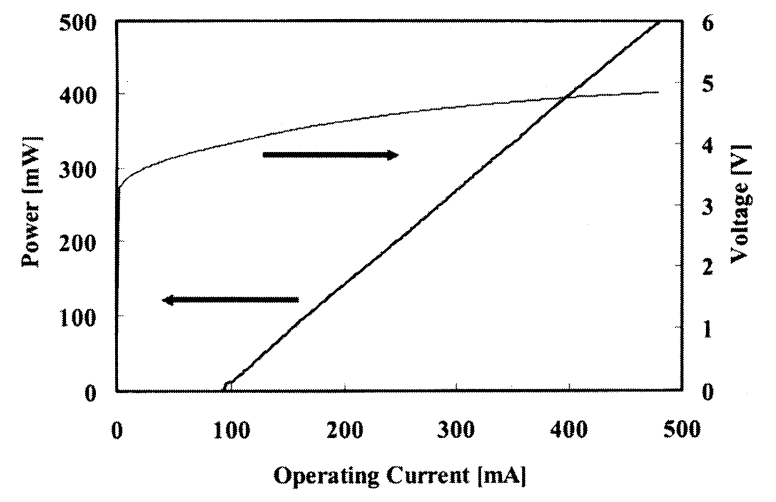

Fig. 7 Typical I-L and I-V characteristics of high power blue LDs under cw operation at $25^{\circ} \mathrm{C}$.

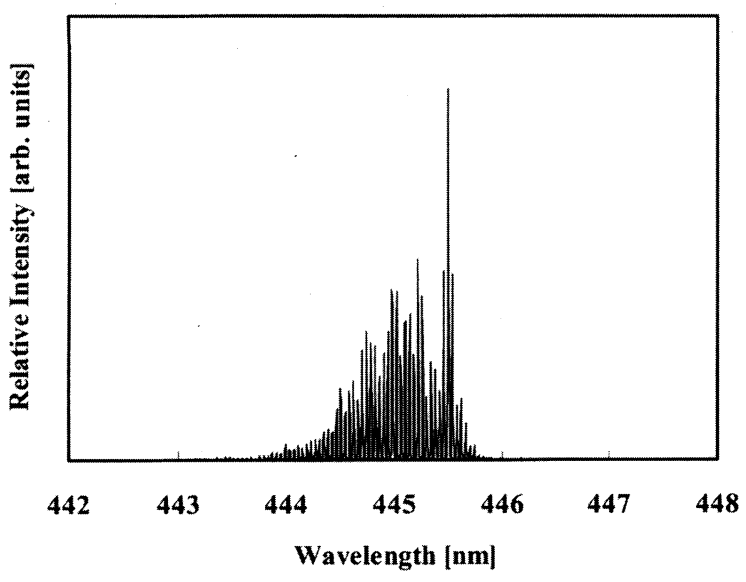

Fig. 8 Emission spectra of blue LDs measured at an output power of $500 \mathrm{~mW}$ under $\mathrm{cw}$ operation.

響で約 $1.2 \mathrm{~W}$ 程度のところで飽和したのに対し，パルス電 流で駆動した場合は，スロープ効率が飽和せずに光出力 が最大で $2.5 \mathrm{~W} ま て ゙$ 駆動することができた。この結果は， 作製した青色半導体レーザーが，COD等による破壊レ心゙ ルが非常に高いことを示唆しており， GaN系材料の堅牢さ を実証する結果であると思われる，また，今回レーザー 素子を実装したパッケージは，熱容量が小さく，熱抵抗 が比較的大きな $\phi 5.6 \mathrm{~mm}$ の汎用ステムである. 光出力が 1 $\mathrm{W}$ 超える高出力化に関しては，この汎用ステムより熱抵 抗の小さなパッケージを採用することで，比較的容易に 達成することが可能であると考えられる.

Fig. 10に，この青色レーザーの寿命試験結果を示す。測 定は, 光出力が500 $\mathrm{mW}$ になるときの電流をレーザー素子 に駆動 (ACC駆動; Auto Current Controller) し，個々のレー ザーの光出力の経時変化をモニターした。1000時間経過 後の劣化係数 $(\delta L / \delta t)$ から, 平均の推定半減期は, 約 1 万時 間以上と見積もられ，信頼性の高いレーザーが得られて いることが分かる。

\section{4. 結 論}

GaN系材料を用いた波長 $405 \mathrm{~nm}$ 紫色レーザーは研究開 発が完了し, 大容量光メモリに必要な特性を十分得られ ている. 今後, 大容量光メモリは高速記録化や多層記録 化が進むと思われるため, 紫色半導体レーザーにはさら

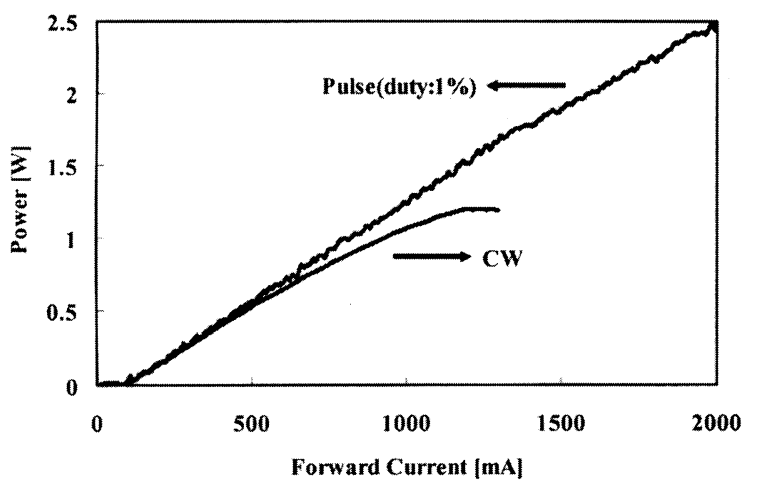

Fig. 9 I-L characteristics of blue LDs by cw and pulsed current operation at $25^{\circ} \mathrm{C}$.

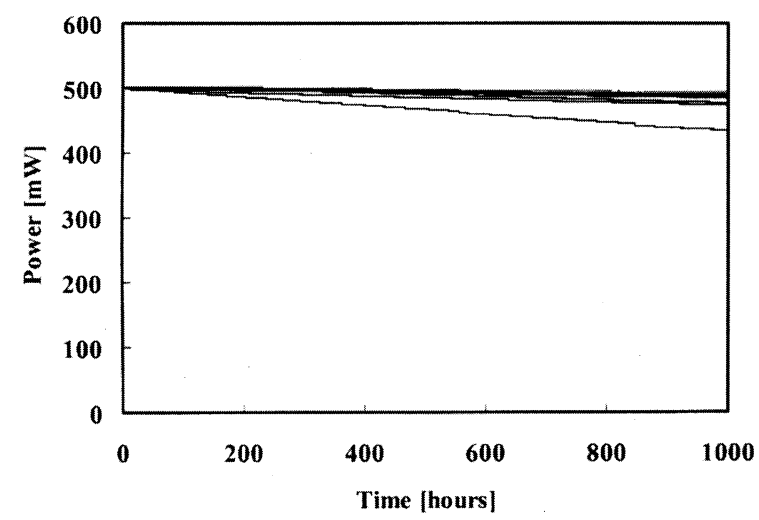

Fig. 10 Result of lifetime test under ACC with an output power of $500 \mathrm{~mW}$ at $25^{\circ} \mathrm{C}$.

に高い光出力が求められる. 今後の課題として, さらな る高出力化 (200 mW以上), また, ノイズ特性やビーム形 状の低アスペクト比化などの特性の改善によって，ビー ムの利用効率を高めることなどが挙げられる。

また，カラー表示用としての青色半導体レーザーにお いては, 光出力 $0.5 \mathrm{~W}$ まで高出力化が進み, 加えて高い信 頼性も確保できている. 今後さらなる高出力化に関して は, チップ構造の最適化, 低熱抵抗パッケージの採用等 が必要であると思われる。

\section{参考文献}

1) S. Nakamura, M. Senoh, S. Nagahama, N. Iwasa, T. Yamada, T. Mastushita, H. Kiyoku, and Y. Sugimoto: Jpn. J. Appl. Phys. 37 (1996) L74.

2) S. Masui, Y. Matsuyama, T. Yanamoto, T. Kozaki, S. Nagahama, and T. Mukai: Jpn. J. Appl. Phys. 42 (2003) L1318.

3) K. Kozaki, T. Yanamoto, T. Miyoshi, Y. Fujimura, S. Nagahama, and T. Mukai: 2005 International Symposium Digest of Technical Papers 36 (2005) 1605.

4) S. Nagahama, N. Iwasa, M. Senoh, T. Matsushita, Y. Sugimoto, H. Kiyoku, T. Kozaki, M. Sano, H. Matsumura, H. Umemoto, K. Chocho, and T. Mukai: Jpn. J. Appl. Phys. 39 (2000) L647.

5) K. Motoki, T. Okahisa, N. Matsumoto, M. Matsushita, H. Kimura, H. Kasai, K. Takemoto, K. Uematsu, T. Hirano, M. Nakayama, S. Nakahata, M. Ueno, D.Hara, Y. Kumagai, A. Koukitu, and H. Seki: Jpn. J. Appl. Phys. 40 (2001) L140.

6) Y. Narukawa, Y. Kawakami, M. Funoto, Sz. Fujita, Sg. Fujita, and S. Nakamura: Appl. Phys. Lett. 70 (1997) 981.

7) S. Chichibu, K. Wada, and S. Nakamura: Appl. Phys. Lett. 71 (1997) 2346.

8) 稲森 正彦, 近藤哲也, 天野浩, 赤崎勇: 電子情報通信学会 信学技報 (1994) p. 13. 